\title{
HYDROGEN SULFIDE ADSORPTION FROM NATURAL GAS AND ITS
} TREATMENT

\author{
Ibrahimov Ch.Sh. ${ }^{1}$, Yusubov F.V. ${ }^{2}$ Email: Ibrahimov17101@ scientifictext.ru
}

\author{
${ }^{1}$ Ibrahimov Chingiz Shirin oglu - Doctor Of Technical Sciences, Professor; \\ ${ }^{2}$ Yusubov Fakhraddin Vali oglu - Doctor Of Technical Sciences, Professor, \\ DEPARTMENT OF PETROCHEMICAL TECHNOLOGY AND INDUSTRIAL ECOLOGY, FACULTY OF CHEMICAL \\ TECHNOLOGY, \\ AZERBAIJAN STATE UNIVERSITY OF OIL AND TECHNOLOGY, \\ BAKU, REPUBLIC OF AZERBAIJAN
}

\begin{abstract}
: one of the advanced methods of low sulfurousgas desulfurization is the adsorption method which provides cost efficient results when extracting trace contaminants from gases. This article contains findings of the researches conducted in the field of adsorption-catalytic extraction of $\mathrm{H}_{2} \mathrm{~S}$ from low sulfurous natural gases and its conversion into elemental sulfur using the synthetic CaA zeolite and natural modified adsorber mordenite as well as the palladium catalyst.

The technological scheme of the processes of adsorption and catalytic isomerization of $\mathrm{H}_{2} \mathrm{~S}$ was developed, catalysts and zeolites were proposed for these purposes, as well as balanced, kinetic and output data of $\mathrm{H}_{2} \mathrm{~S}$ adsorption, dependence of the degree of converions of $\mathrm{H}_{2} \mathrm{~S}$ into elementral sulfur on the time of desorption, concentration of $\mathrm{H}_{2} \mathrm{~S}$ in the strippant, temperature of reaction and volume velocity of the desorbing gas in the reactor were obtained.
\end{abstract}

Keywords: natural gas, $\mathrm{H}_{2} \mathrm{~S}$, cleaning, adsorption.

\author{
ВЫДЕЛЕНИЕ СЕРОВОДОРОДА ИЗ ПРИРОДНОГО ГАЗА И ЕГО \\ ОБЕЗВРЕЖИВАНИЕ \\ Ибрагимов Ч.Ш. ${ }^{1}$, Юсубов Ф.В. ${ }^{2}$ \\ ${ }^{1}$ Ибрагимов Чингиз Ширин огль - доктор технических наук, профессор \\ ${ }^{2}$ Юсубов Фахраддин Вали огль - доктор технических наук, профессор, \\ кафедра нефтехимической технологии и промылиленной экологии, химико-технологический факультет, \\ Азербайджанский государственный университет нефти и промышленности, \\ г. Баку, Азербайджанская Республика
}

\begin{abstract}
Аннотация: одним из передовых методов десульфирования с низким содержанием серы является адсорбиионный метод, который обеспечивает экономически эффективные результаты при извлечении микропримесей из газов. Данная статья содержит результаты исследований, проведенных в области адсорбционно-каталитической экстракции $\mathrm{H}_{2} \mathrm{~S}$ из низкосернистых природных газов и ее превращчения 8 элементарную серу с использованием синтетического иеолита СаА и модифицированного природным адсорбентом морденита, а также палладиевого катализатора.

Разработана технологическая схема прочессов адсорбции и каталитической изомеризаџии $\mathrm{H}_{2} S$, предложены для этих иелей катализаторы и иеолиты, а также сбалансированные, кинетические и выходные данные по адсорбции $H_{2} S$, зависимость степени конверсии $H_{2} S$ в элементарной сере. Были получены время десорбции, концентрация $\mathrm{H}_{2} \mathrm{~S}$ в иламе, температура реакции и объемная скорость десорбирующего газа в реакторе.
\end{abstract}

Ключевые слова: природный газ, $\mathrm{H}_{2} S$, очистка, адсорбиия.

UDC 66.011.001

Critical to a certain extent situation which develops around natural gas processing is primarily defined by sulfur compounds content in it that leads to catalyst poisoning and environment contamination with sulfur industrial wastes [1-3].

With continuous improvement of gas desulfurization processes there are still many issues that are to be resolved. The problem of creation and development of methods of practically absolute natural gas cleaning against any undesirable ingredients combined with high efficiency and cost effectiveness of the technological process providing an acceptable ecological setting dominates among such issues.

This paper describes the following problem-solving results.

For the first time, a mathematical model of hydrogen sulfide adsorption from low sulfurous natural gases and the process of conversion of $\mathrm{H}_{2} \mathrm{~S}$ into elementalsulfur by catalytic oxidation in a plant of similar combination continuously and consistently was developed. Researches were conducted in the field of selection of effective adsorbents and catalysts for the considered process, and the results of the experiments analysis have shown that hydrogen sulfide adsorption from low sulfurous natural gases was more effective in CaA zeolite (activity 120 
$\mathrm{mg} / \mathrm{g}$ ). At the same time it was determined that use of modified natural mordenite was more reasonable in terms of cost effectiveness $(15 \mathrm{mg} / \mathrm{g})$. Conversion of $\mathrm{H}_{2} \mathrm{~S}$ into elementalsulfur by catalytic oxidation was performed using palladium catalysts.

A mathematical model of the processes of hydrogen sulfide adsorption from low sulfurous natural gases and catalytic oxidation was developed to provide an optimal design of these processes, the method of analytic solution was found to facilitate its practical application, and the method to confirm parameter identification was developed.

So, the method to confirm designing and management of the plant and continuous coordinated operation of the processes of hydrogen sulfide adsorption from low sulfurous natural gases and conversion of $\mathrm{H}_{2} \mathrm{~S}$ into elementalsulfur by catalytic oxidation which provides the practical significance of this paper has been developed.

Experimental: The adsorption method of hydrogen sulfide removal is effective when natural gas contains less than $5 \% \mathrm{H}_{2} \mathrm{~S}$. Synthetic zeolites of $\mathrm{NaA}, \mathrm{NaX}, \mathrm{CaA}, \mathrm{NaY}, \mathrm{NaA}$, etc. are used for this purpose.However use of the adsorption method entails the problem of utilization of extracted $\mathrm{H}_{2} \mathrm{~S}$. It is known that application of the Claus' method to low sulfurous natural gases is not always effective. Grigoryeva N.A., Jagfarov F.G. Design of the sulfur recovery unit using the Claus' method. Moscow, 2006.

Taking into account the abovementioned, this paper proposes a technological scheme (Figure 1) of $\mathrm{H}_{2} \mathrm{~S}$ extraction and utilization. Low sulfurous natural gas is fed to the adsorber A-1 or A-2 under $6 \mathrm{MPa}$ where hydrogen sulfide is adsorbed on zeolite $\mathrm{CaA}$ after $\mathrm{H}_{2} \mathrm{~S}$ saturation of which the adsorber is switched over the desorption mode. A part of raw gas preheated in the furnace $\mathrm{P}-1$ up totemperature $250-300^{\circ} \mathrm{C}$ is used as the desorbing agent. Desorbed hydrogen sulfide together with desorbing gas is fed to the converter (reactor 1) through line $\mathrm{V}$ where the reaction of oxidation of $\mathrm{H}_{2} \mathrm{~S}$ takes place and elemental sulfur is produced on the palladium catalyst synthesized for this purpose at temperature $270-290^{\circ} \mathrm{C}$.

Since the temperature of the regeneration gas at outlet from the desorber is about temperature $300^{\circ} \mathrm{C}$ and the oxidation reaction is exothermic, no change in its temperature in the reactor is needed. This is one of the causes of cost effectiveness of use of this technological system.

The experimental design method was used for experimentation. As a result, a regression equation linking the degree of conversion of hydrogen sulfide $(S)$ into elemental sulfur with the parameters of adsorption and reactor sections of the plant was obtained as follows:

$\mathrm{S}=5,67-0,32 \cdot \mathrm{t}+0,415 \cdot \mathrm{T}-4,47 \cdot \mathrm{C}_{\mathrm{d}}+0,81 \cdot 10^{-2} \cdot \mathrm{V}+0,39 \cdot 10^{-2} \bullet t \cdot \mathrm{T}-0,056 \cdot \mathrm{C}_{\mathrm{d}}-0,16 \cdot 10^{-3} \cdot \mathrm{t} \cdot \mathrm{V}-0,014 \cdot \mathrm{T} \bullet \mathrm{C}_{\mathrm{d}}-$ $0,59 \cdot 10^{-4} \cdot \mathrm{T} \cdot \mathrm{V}+0,25 \cdot 10^{-2} \cdot \mathrm{C}_{\mathrm{d}} \cdot \mathrm{V}$

Here, $\mathrm{S}, \%$ is the degree of conversion of hydrogen sulfide into elemental sulfur; $\mathrm{t}$, hour is $\mathrm{H}_{2} \mathrm{~S}$ desorption time; $\mathrm{T},{ }^{0} \mathrm{C}$ is the temperature of reaction; $\mathrm{C}_{\mathrm{d}}, \%$ is the concentration of $\mathrm{H}_{2} \mathrm{~S}$ in the strippant; V, hour-1 is the volume rate of the desorbing gas in the reactor. Some experimental materials are given in Figures 2-3 and Table 1. Isothermic diagrams and kinetic data of adsorption of $\mathrm{H}_{2} \mathrm{~S}$ from the hydrocarbon blend on CaA zeolite are given in Figures 2 and 3.

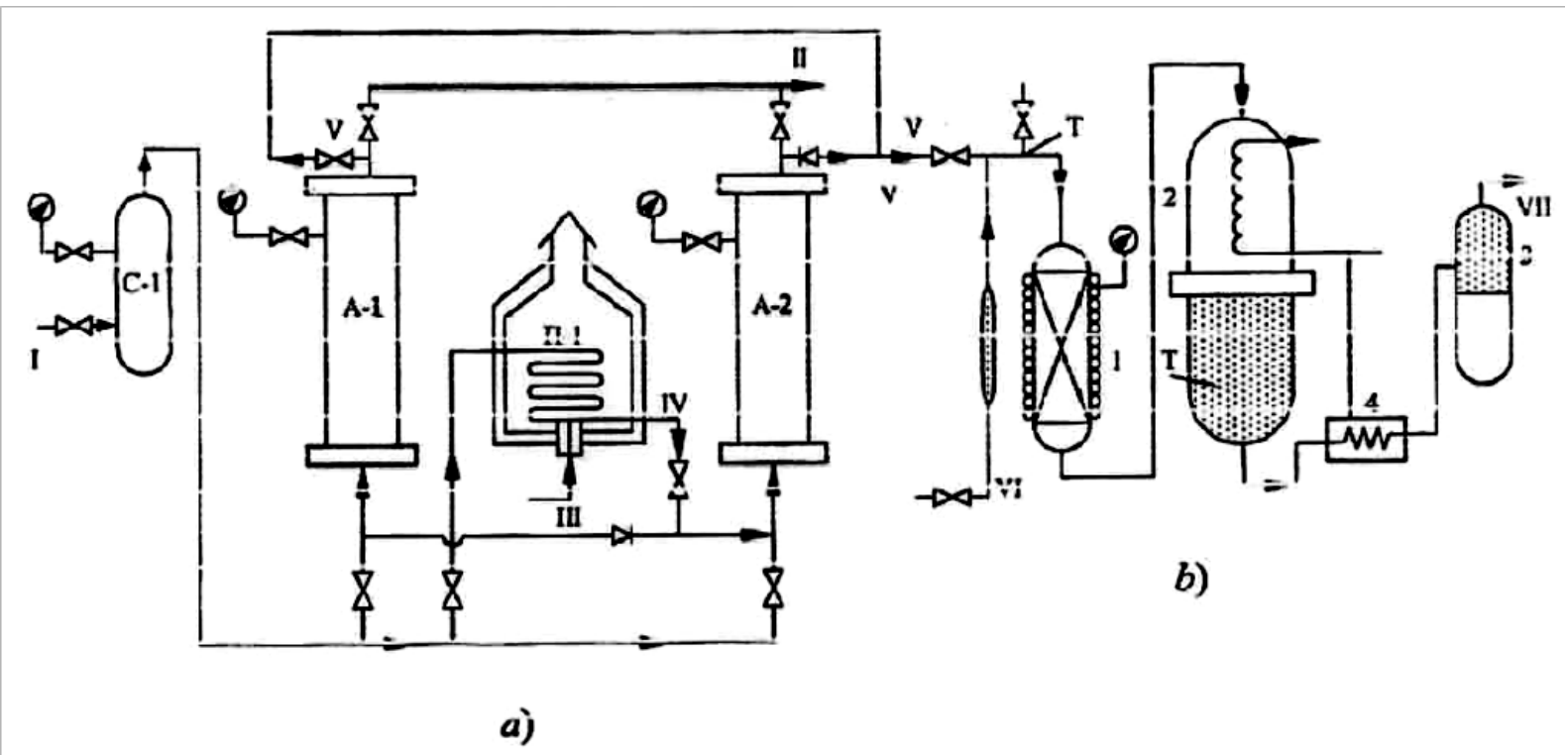

Fig. 1. Technological scheme of hydrogen sulfide adsorption from low sulfurous natural gases and its conversion into elemental sulfur: A-1, A-2 - adsorbers; $C-1$ - separator; $P-1$ - furnace; 1 - converter with catalyst; 2 - coagulator; 3 - sulfur trap; 4 - cooler. Flows: I - raw gas; II - pure gas; III - fuel gas; IV regenerating gas; $V$-desorption products; a) adsorption unit; b) reactor section 


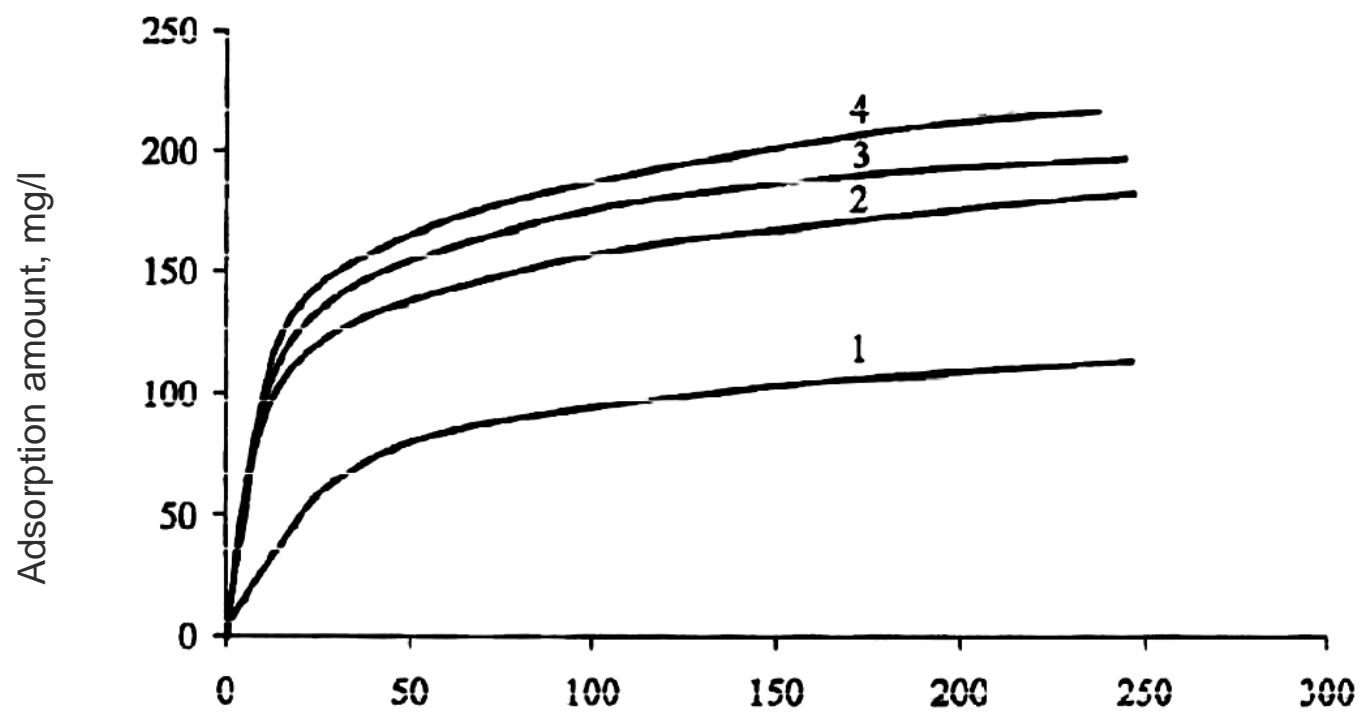

Partial pressure $\mathrm{H}_{2} \mathrm{~S}, \mathrm{~mm} \mathrm{Hg}$

Fig. 2. Isotherms of $\mathrm{H}_{2} \mathrm{~S}$ adsorption on zeoilites of various grades: $1-\mathrm{CaX} ; 2-\mathrm{NaA} ; 3-\mathrm{CaA} ; 4-\mathrm{NaX}$

\section{C. $1 \hat{U}^{3}$ Kzi $^{2}$}

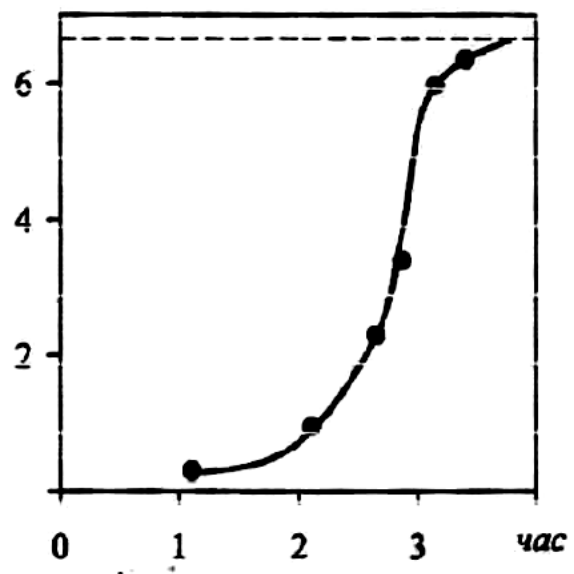

a)

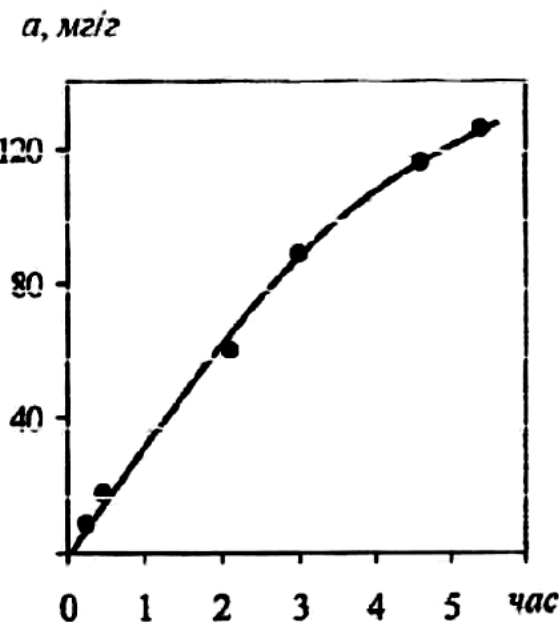

2)

Fig. 3. Elution ( $a$ ) and kinetic (b) curves of $\mathrm{H}_{2} \mathrm{~S}$ adsorption from the hydrocarbon blend of the gas by synthetic CaA zeolite (initial concentration of $\mathrm{H}_{2} \mathrm{~S}$ in gas $\mathrm{C}_{0}=6.1 * 10^{-3} \mathrm{~kg} / \mathrm{m}^{3}$ )

Discussion of results: As is seen from Figure 2, the most active zeolite for $\mathrm{H}_{2} \mathrm{~S}$ is $\mathrm{NaX}$. However the use of thise zeolite would be inexpedient in terms of sieve effect as its pore size is about $10 \mathrm{~A}^{0}$. In this case other components of the gas get into active centers of zeolite when passing the pores and reduce its activity against $\mathrm{H}_{2} \mathrm{~S}$. It is advisable, therefore, to use CaA zeolite with pore size not exceeding $5 \mathrm{~A}^{0}$, I.e. corresponding to $\mathrm{H}_{2} \mathrm{~S}$ molecule size.

As is seen from Figures 3, activity of the synthetic CaA zeolite against $\mathrm{H}_{2} \mathrm{~S}$ is by a factor of ten higher that activity of modified natural mordenite. Mordenite is more attractive because it is lower in cost and there are rich resources of natural zeolites in the Azerbaijan Republic [4-7].

Table 1. Comparison of experimental and design data on the degree of conversion of hydrogen sulfide into the elemental sulfur

\begin{tabular}{|c|c|c|c|c|c|c|c|}
\hline № & t, hour & $\mathbf{T}^{\mathbf{0}} \mathbf{C}$ & $\mathbf{C d}, \%$ & $\mathbf{V}, \mathbf{h o u r}-\mathbf{1}$ & $\mathbf{S , \%}(\mathbf{e x})$ & $\mathbf{S , \%}$ & Error \\
\hline 1 & 0.33 & 250 & 3.0 & 2000 & 88.38 & 86.891 & +1.68 \\
\hline 2 & 1.00 & 250 & 6.3 & 2000 & 75.14 & 76.588 & -1.93 \\
\hline 3 & 1.667 & 250 & 4.35 & 2000 & 82.96 & 82.795 & +0.20 \\
\hline
\end{tabular}




\begin{tabular}{|c|c|c|c|c|c|c|c|}
\hline 4 & 0,667 & 250 & 5.1 & 3000 & 85.54 & 86.140 & $-0,70$ \\
\hline 5 & 1,33 & 250 & 6,15 & 3000 & 84.72 & 85.305 & $-0,691$ \\
\hline 6 & 1,33 & 250 & 6,15 & 4000 & 93.69 & 93.555 & $+0,14$ \\
\hline 7 & 0,33 & 300 & 3,75 & 2000 & 96.64 & 96.832 & $-0,20$ \\
\hline 8 & 2,00 & 300 & 3,9 & 2000 & 95.98 & 96.765 & $-0,82$ \\
\hline 9 & 1,00 & 300 & 8,4 & 4000 & 100 & 100.859 & $-0,86$ \\
\hline 10 & 0,33 & 350 & 6,0 & 2000 & 97.17 & 98.921 & $-1,97$ \\
\hline 11 & 2,00 & 350 & 6,75 & 3000 & 100 & 99.815 & +0.19 \\
\hline 12 & 1,33 & 350 & 11.25 & 4000 & 100 & 104.986 & -4.99 \\
\hline
\end{tabular}

Table 1 provides the data as an examplewhich reflect the influence of $\mathrm{H}_{2} \mathrm{~S}$ desorption time in the adsorption unit, temperature of reaction, $\mathrm{H}_{2} \mathrm{~S}$ concentration in the strippant and volume velocity of the desorbing gas in the reactor on the degree of conversion of hydrogen sulfide into the elemental sulfur. The average error of experimental and design data on the degree of conversion of hydrogen sulfide into the elemental sulfur is $+/-$ $1.18 \%$.

The problem of optimization of the process of $\mathrm{H}_{2} \mathrm{~S}$ adsorption from gas was solved using the data of conducted researches.

We obtain the following values of input parameters: quantity of crude gas $-26 \mathrm{t} / \mathrm{hour}$; pressure in the adsorber - $40 \mathrm{~atm}$; adsorbent - CaA zeolite the dynamic activity of which against $\mathrm{H}_{2} \mathrm{~S}$ is $120 \mathrm{mg} / \mathrm{g}$. Based on the practical researches, the following limits were accepted:

$20^{\circ} \mathrm{C} \leq \mathrm{T}_{\mathrm{a}} \leq 80^{\circ} \mathrm{C}$

$250^{\circ} \mathrm{C} \leq \mathrm{T}_{\mathrm{pe}} \leq 300^{\circ} \mathrm{C}$

$0.1 \mathrm{~m} / \mathrm{c} \leq \mathrm{v} \leq 0.7 \mathrm{~m} / \mathrm{c}$

$0.001 \mathrm{~kg} / \mathrm{m}^{3} \leq \mathrm{C}_{0} \leq 0.1 \mathrm{~kg} / \mathrm{m}^{3}$

where $\mathrm{T}_{\mathrm{a}}$ - temperature of adsorption; $\mathrm{T}_{\mathrm{pe}}$ - temperature of reaction; $\mathrm{v}$ - linear velocity of gas feeding to adsorber; $\mathrm{C}_{0^{-}}$initial concentration of $\mathrm{H}_{2} \mathrm{~S}$ in the original (feed) gas.

Costs given for one cycle of periodical adsorption were selected as an optimality criterion. In the result the following optimal values of parameters were obtained: the period of adsorption is $24 \mathrm{~h}$; the gas flow velocity is $0.36 \mathrm{~m} / \mathrm{sec}$; the temperature of adsorption is $22^{\circ} \mathrm{C}$; the temperature of regeneration is $265^{\circ} \mathrm{C}$; the adsorber diameter is $1.95 \mathrm{~m}$; the quantity of adsorbent in one adsorber is $13202 \mathrm{~kg}$; the adsorbent layer height is $6.3 \mathrm{~m}$.

Conclusion:

1. The technological scheme of $\mathrm{H}_{2} \mathrm{~S}$ adsorption from low sulfurous natural gases and its conversion into elementalsulfur was developed.

2. The experimental design method was used to create a regression equation linking the degree of conversion of hydrogen sulfide into elemental sulfur with the parameters of adsorption and reactor sections of the plant.

3. Zeolites which provide the most effective results for the process considered in this paper were selected.

4. The following was obtained: a) experimental balanced, kinetic and output data of $\mathrm{H}_{2} \mathrm{~S}$ adsorption; b) dependence of the degree of conversion of $\mathrm{H}_{2} \mathrm{~S}$ into elemental sulfur on the time of its desorption in the adsorption unit, temperature of reaction, concentration of $\mathrm{H}_{2} \mathrm{~S}$ in the strippant and volume velocity of the desorbing gas in the reactor.

\section{References / Сиисок литературы}

1. Conference of United Nations Organization by climate problems, Paris (12.12.2015).

2. Ahnazarova S.L., Gafarov V.V.: Optimization experiment in Chemistry and Chemical Engineering, Graduate School, Moscow, 1978. C. 126-132.

3. Ibragimov Ch.Sh. To design and management methods of the adsorption process. Elm. Baku, 1999. C. 145147.

4. Keltsev N.V. Base of adsorbtivetechnige, Chemistry. Moscow, 1984. C. 138-141.

5. General course of processes and chemical engineering apparatuses: Textbook: in 2 volumes / V.G. Einstein, M.K. Zakharov, G.A. Nosov, etc. M: Logos; Higher school, Moscow, 2002. C. 1157-1175.

6. Qorbatenko Y.A. Adsorption of admixtures of toxical gas from polluted air. Yekaterinburg, 2014. $47 \mathrm{c}$.

7. Renato R., Phillip W. İntensification of pressure swing adsorption processes. // Aiche Journal, 1990.36. № 9. P. 1299-1312. 